Gynecologic and Obstetric Investigation

\section{N.C. Seçkin \\ N.Ö. Turhan}

G. Dilmen

Fetih University, Faculty of Medicine,

Emek-Ankara, Turkey
Dear Sir,

The use of ovulation-inducing agents in the treatment of infertility is increasing [1, 2], and there has been considerable concern that follicular stimulation may potentially increase the risk of epithelial ovarian cancer $[1,3]$. Also, it is suggested that hormonal alterations associated with the use of ovulation-inducing agents may influence breast cancer risk [2]. Nevertheless, it is surprising that until now there has never been any controlled study.

We met two young women with breast cancer within a short period who had been exposed to ovulation-inducing agents for infertility treatment. One of them was a $42-$ year-old nulliparous woman who does not have any first-degree relatives with breast cancer. At the end of 1 year of failed ovulation induction with high-dose $\mathrm{HMG}+\mathrm{HCG}$, she was diagnosed as having breast cancer (infiltrating intraductal carcinoma tested positive for estrogen and progesterone receptors) when she was 41 .

The other patient was a 32-year-old woman, gravida 2, para 1, 34 weeks pregnant. She was 29 years old when she was first diagnosed as having breast cancer (infiltrating intraductal carcinoma tested positive for estrogen receptors). She does not have any first-degree relatives with breast cancer. Her

\title{
Ovulation Induction and Breast Cancer
}

two pregnancies took place after ovulation induction with clomiphene citrate and $\mathrm{HMG}+\mathrm{HCG}$.

The authors who first drew attention to the possible link between ovulation induction and breast cancer were Laing et al. [4] in 1989. After 4 years, Brzezinski et al. [1] from Jerusalem and in 1995 Jourdain et al. [5] suggested that follicular stimulation may promote breast cancer. All the patients described were relatively young at the time when the breast cancers were diagnosed. We met two such young patients within a short period of time in our outpatient clinic, which does not serve basically as an infertility center. What alarmed us is the fact that ovulation inductions can now be done by any gynecologist, usually without warning the patients about the problem; yet we are not sure that even they are aware of this problem because of the lack of sufficient and pertinent data.

To conclude, we propose that until the problem is investigated by large controlled studies, the physicians who are responsible for ovulation induction must be extremely careful and monitor the patients throughout their lives for this disastrous disease to prevent at least such iatrogenic cases, even if its incidence is on the increase.

\section{References}

1 Brzezinski A, Peretz T, Mor-Yosef S, Schenker JG: Ovarian stimulation and breast cancer: Is there a link? Gynecol Oncol 1994;52:292-295.

2 Rossing MA, Daling JR, Weiss NS, Moore DE, Self SG: Risk of breast cancer in a cohort of infertile women. Gynecol Oncol 1996;60:3-7.

3 Herbst AL: The epidemiology of ovarian carcinoma and the current status of tumor markers to detect disease. Am J Obstet Gynecol 1994; 170:1099-1107.

4 Laing RW, Glaser MG, Barret GS: A case of breast carcinoma in association with in vitro fertilization. J R Soc Med 1989;82:503.

5 Jourdain O, Avril A, Mauriac L, Gaillard F, Stockle E, Bussières E: Cancer du sein et traitment par hMG: Y a-t-il un lien? J Gynecol Obstet Biol Reprod 1995;24:679-682.

\section{KARGER}

Fax + 41613061234 E-Mail karger@karger.ch www. karger.com (c) 1998 S. Karger AG, Basel

0378-7346/98/0452-0144\$15.00/0

This article is also accessible online at: http://BioMedNet.com/karger
Neslihan Carda Seçkin, MD

And. Sok. 32/7

TR-06680 Cankaya, Ankara (Turkey)

Tel. +90 31246822 50, Fax +90 3122210375 